\title{
SPECC1 wt Allele
}

National Cancer Institute

\section{Source}

National Cancer Institute. SPECC1 wt Allele. NCI Thesaurus. Code C97532.

Human SPECC1 wild-type allele is located in the vicinity of $17 \mathrm{p} 11.2$ and is approximately $310 \mathrm{~kb}$ in length. This allele, which encodes cytospin-B protein, may play a role in nuclear structure. A chromosomal translocation t(5;17)(q33;p11.2) of this gene and the PDGFRB gene is associated with juvenile myelomonocytic leukemia. 